\title{
Float, explode or sink: postmortem fate of lung-breathing marine vertebrates
}

\author{
Achim G. Reisdorf • Roman Bux • Daniel Wyler • \\ Mark Benecke • Christian Klug • Michael W. Maisch • \\ Peter Fornaro • Andreas Wetzel
}

Received: 20 October 2011 /Revised: 16 December 2011 / Accepted: 22 December 2011 / Published online: 1 February 2012

(C) Senckenberg Gesellschaft für Naturforschung and Springer 2012

\begin{abstract}
What happens after the death of a marine tetrapod in seawater? Palaeontologists and neontologists have claimed that large lung-breathing marine tetrapods such as ichthyosaurs had a lower density than seawater, implying that their carcasses floated at the surface after death and sank subsequently after leakage of putrefaction gases (or "carcass explosions"). Such explosions would thus account for the skeletal disarticulation observed frequently in the fossil record. We examined the taphonomy and sedimentary environment of numerous ichthyosaur skeletons and compared them to living marine tetrapods, principally cetaceans, and measured abdominal pressures in human carcasses. Our data and a review of the literature demonstrate that carcasses sink and do not explode (and spread skeletal elements). We argue that the normally
\end{abstract}

This article is a contribution to the special issue "Taphonomic processes in terrestrial and marine environments"

A. G. Reisdorf $(\bowtie) \cdot$ A. Wetzel

Geologisch-Paläontologisches Institut, Universität Basel,

Bernoullistrasse 32,

4056 Basel, Switzerland

e-mail: Achim.Reisdorf@unibas.ch

\section{R. Bux}

Institut für Rechtsmedizin und Verkehrsmedizin,

Universitätsklinikum Heidelberg,

Voßstrasse 2, Gebäude 4420,

69115 Heidelberg, Germany

D. Wyler

Pathologie und Rechtsmedizin, Kantonsspital,

Loëstrasse 170,

7000 Chur, Switzerland

\section{Benecke}

Internatinal Forensic Research \& Consulting,

Postfach 250411,

50520 Köln, Germany slightly negatively buoyant carcasses of ichthyosaurs would have sunk to the sea floor and risen to the surface only when they remained in shallow water above a certain temperature and at a low scavenging rate. Once surfaced, prolonged floating may have occurred and a carcass have decomposed gradually. Our conclusions are of significance to the understanding of the inclusion of carcasses of lung-breathing vertebrates in marine nutrient recycling. The postmortem fate has essential implications for the interpretation of vertebrate fossil preservation (the existence of complete, disarticulated fossil skeletons is not explained by previous hypotheses), palaeobathymetry, the physiology of modern marine lung-breathing tetrapods and their conservation, and the recovery of human bodies from seawater.

\author{
C. Klug \\ Paläontologisches Institut und Museum, \\ Universität Zürich, \\ Karl Schmid-Strasse 4, \\ 8006 Zürich, Switzerland
}

M. W. Maisch

Institut für Geowissenschaften,

Eberhard Karls-Universität Tübingen,

Hölderlinstr. 12,

72074 Tübingen, Germany

P. Fornaro

Imaging and Media Lab, Universität Basel,

Bernoullistrasse 32,

4056 Basel, Switzerland 
Keywords Ichthyosaur · Nekton falls · Taphonomy . Fossillagerstätten · Early Jurassic sea-level · Forensic sciences $\cdot$ Whales

\section{Introduction}

Large vertebrate fossils such as ichthyosaurs are spectacular documents of earth history, but uniformitarian studies of the fate of large vertebrate carcasses in shallow marine environments before fossilization are rare (Britton and Morton 1994; Dahlgren et al. 2006; Glover et al. 2005; Liebig et al. 2007; Schäfer 1972; Smith 2007a). Recent studies have mainly dealt with decomposition of vertebrate carcasses in the deep sea (e.g., Glover et al. 2008; Kemp et al. 2006; King et al. 2006; Smith and Baco 2003). Because of the usual lack of food at the deep-sea floor, the scavenging rate on carcasses can be much higher than in shallow marine habitats (Bozzano and Sardà 2002; Janßen et al. 2000; Kemp et al. 2006). Consequently, direct comparisons between deep and shallow marine habitats are of only limited value (e.g., Fujiwara et al. 2007; Martill et al. 1995; Smith 2007a), since physical, chemical, and microbial decomposition are significantly more important than scavenging in the shallow-water (Anderson and Hobischak 2004; Kahana et al. 1999; Mosebach 1952; Petrik et al. 2004; Smith and Baco 2003).

We thus examined peri- and postmortem processes concerning carcasses of lung-breathing vertebrates in a shallow marine regime by applying palaeontological, sedimentological, forensic, anthropological, archaeological, veterinary, marine biological, and trophological methods. This integrative approach enabled us to falsify several previously applied hypotheses to explain taphonomic phenomena. It is our aim to portray the processes involved in the stratinomy of lung-breathing vertebrates, to falsify some old hypotheses, and to discuss possible applications.

Ichthyosaurs represent a diverse group of extinct marine reptiles which were almost cosmopolitan during most of the Mesozoic [245-90 million years ago (Ma); Gradstein et al. 2004; McGowan and Motani 2003]. Although these fossil lung-breathing tetrapods exhibit a whole set of morphological characters which evolved convergently to the Odontoceti (cetaceans), it has been assumed that ichthyosaur bodies had a lower density than seawater (e.g., McGowan 1992; McGowan and Motani 2003; Taylor 1987, 2001). The prevailing interpretation implies that ichthyosaurs drifted after death for a while at the sea surface and the preservation quality decreased with the floating duration (e.g., Fröbisch et al. 2006; Long et al. 2006; Martill 1986, 1993). The carcasses sank finally to the sea-floor only after leakage of the putrefaction gas, often by bursting (e.g., Cruickshank and Fordyce 2002; Kuhn-Schnyder 1974; Long et al. 2006; Martill 1993; commonly called "carcass explosion").
Ichthyosaurs were probably able to dive to depths exceeding 500 m (Dollo 1907; Humphries and Ruxton 2002; McGowan and Motani 2003). This inference can be drawn from the absence of ossified tracheas in fossil ichthyosaurs, which can otherwise be preserved in great detail in marine crocodiles of the same age and localities as the ichthyosaur finds (e.g., Westphal 1962). A more or less ossified trachea limits diving depth (Mason and Macdonald 1986; Tarasoff and Kooyman 1973), and the tracheas of Recent, deep-diving lung-breathers are cartilaginous (Kooyman 1989). Such cartilaginous tracheas are usually not preserved in the fossil record.

\section{Exploding the myth: can carcasses explode?}

"Carcass explosion" was first discussed among palaeontologists and geologists 32 years ago (Keller 1976), when studying the Early Jurassic Posidonienschiefer Formation (Bloos et al. 2005; ca. 183-181 Ma) of Germany. These black shales were deposited at depths between 50-150 m (Röhl et al. 2001) and contain exceptionally well-preserved remains of ichthyosaurs and other marine tetrapods (Hauff 1921; Hofmann 1958; Martill 1993). The excellent fossil preservation within finely laminated, unbioturbated black shales was explained with the widely accepted classic "stagnant basin model" (Keller 1976; Pompeckj 1901). The ichthyosaur skeletons are usually complete but disarticulated to varying degrees (Hauff 1921; Hofmann 1958). Therefore, "carcass explosion" appeared to be a reasonable explanation. It was assumed that carcasses which lie on the sea-floor might have exploded or internal organs and bones erupted, and that in so doing, bones as well as fetuses were ejected and ribs were fractured (Fig. 1; e.g., Böttcher 1989; Hofmann 1958; Keller 1976; Martill 1993). In spite of the lack of (direct) evidence for these processes, these ideas have never been questioned.

These classic models rely on the observation that beached Cetacean carcasses can get inflated impressively by putrefaction gases within hours (=bloated stage; Malakoff 2001; Schäfer 1972; Smith and Baco 2003; Stede et al. 1996; Tønnessen and Johnsen 1982). This process is mainly initiated by the activity of intestinal bacteria (=intrinsic flora; Daldrup and Huckenbeck 1984; Fiedler and Graw 2003; Mallach and Schmidt 1980; Robinson et al. 1953; Stevens and Hume 1998). Postmortem bacterial activity is highly variable because it depends on numerous factors such as the type of bacteria involved, the cause of death, injuries, and composition and amount of ingested food, as well as environmental conditions (Bajanowski et al. 1998; Daldrup and Huckenbeck 1984; Keil et al. 1980; Mallach and Schmidt 1980; Pedal et al. 1987; Pierucci and Gherson 1968; Rodriguez 1997; Sakata et al. 1980). Putrefaction rates decelerate with decreasing (water) temperature (Bonhotal et al. 2006; Dickson et al. 2011; Haberda 1895; Padosch et al. 
Fig. 1 Ichthyosaur skeleton with approximately 10 embryos, Holzmaden (Germany), Posidonienschiefer Formation (Stenopterygius, specimen SMNS 50007; drawing modified after Böttcher 1990; image by courtesy of Staatliches Museum für Naturkunde Stuttgart). In contrast to the skeleton of the mother, most of the embryonal skeletons are largely disarticulated. Many embryonal bones are scattered far beyond the body limits of the mother. Böttcher (1990) explained this arrangement by a displacement of already disarticulated embryos during the expulsion of putrefaction gases through the ruptured body wall of the mother. Osborn (1905) explained such phenomena by currents
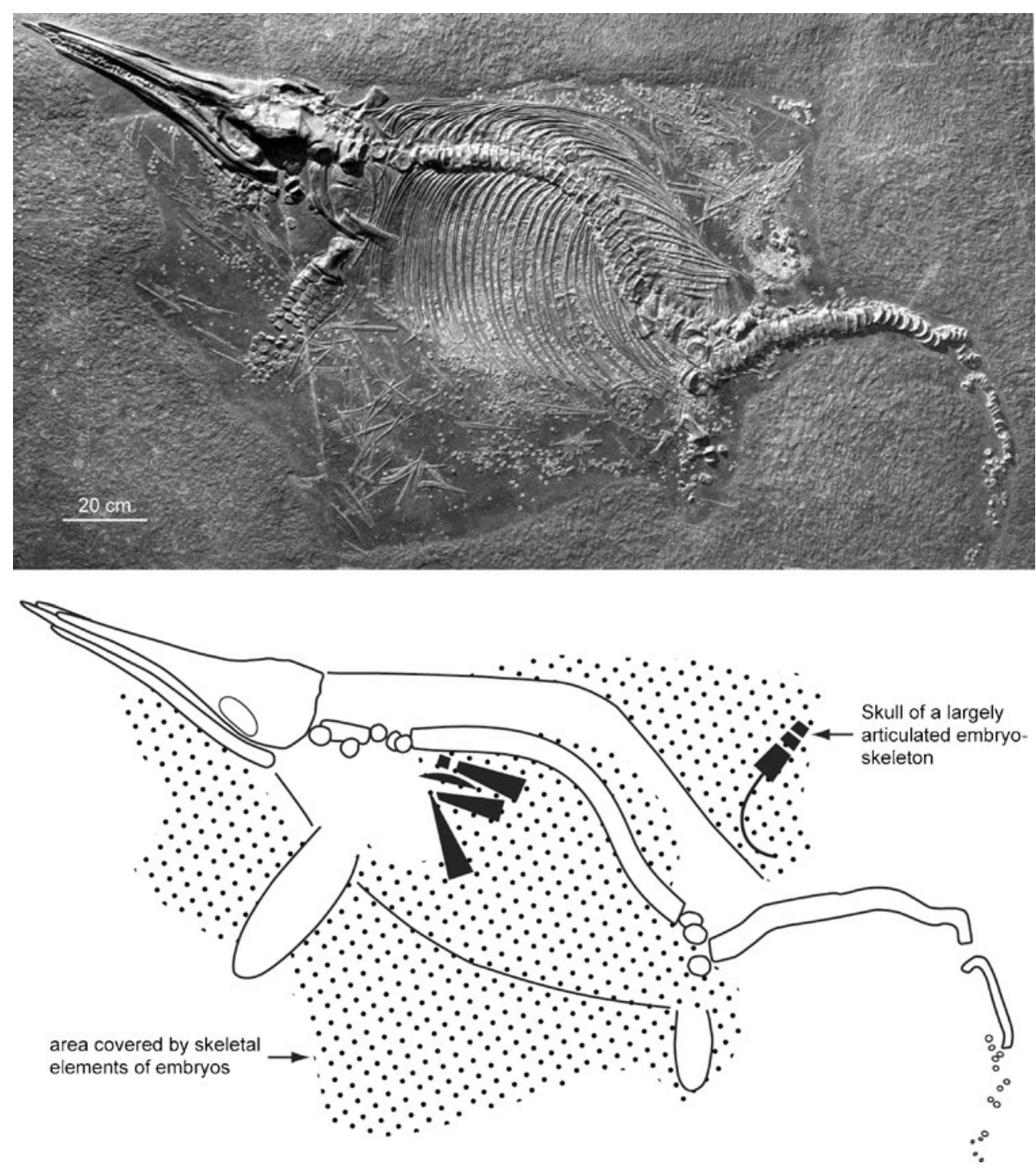

2005; Petrik et al. 2004; Robinson et al. 1953). Decay by intestinal bacteria (e.g., Clostridia, Escherichia) all but halts below $4^{\circ} \mathrm{C}$, while enzymes (=autolysis) remain active until $-5^{\circ} \mathrm{C}$ (Jauniaux et al. 1998; Keil et al. 1980; Lochner et al. 1980; Robinson et al. 1953; Sharp and Marsh 1953; Vass et al. 2002; compare Rollo et al. 2007). In aquatic environments, putrefaction and autolysis progresses most rapidly at low hydrostatic pressures within an intact, large, cylindrical and well-insulated carcass (e.g., a whale; Hood et al. 2003; Innes 1986; McLellan et al. 1995; Robinson et al. 1953; Worthy and Edwards 1990), independent of oxygen availability. When an inflated carcass experiences mechanical stress such as inappropriate transport or dissection, body liquids and internal organs may be ejected from the carcass (Fig. 2; Anonymous 2004; Stede 1997; Tigress Productions 2008; Tønnessen and Johnsen 1982). There is no evidence for skeletal elements being included in such "eruptions".

During the Toarcian, the conditions in the European epeiric sea were favourable for putrefaction and autolytical processes, because the sea surface temperature has been estimated to have varied between 25 and $30^{\circ} \mathrm{C}$ (Röhl et al. 2001).

In spite of the adaptations to the marine habitat, it is still probable that sometime after death seawater containing anaerobic or aerobic bacteria intruded both digestive and respiratory tracts of ichthyosaurs because of the hydrostatic pressure (=exogenous bacteria; e.g., Eisele 1969; Hänggi and Reisdorf 2007; Kakizaki et al. 2008; Siebert et al. 2001; Sims et al. 1983). Onset of putrefaction processes due to exogenous bacteria is thus conceivable (as in human carcasses; Davis 1986; Dickson et al. 2011; Lunetta et al. 2002; Mallach and Schmidt 1980; Padosch et al. 2005; Tomita 1975, 1976). The putrefaction gases produced by the intrinsic bacteria but probably also by exogenous bacteria comprise $\mathrm{CO}_{2}, \mathrm{H}_{2}, \mathrm{~N}_{2}$, to a lesser amount $\mathrm{CH}_{4}, \mathrm{H}_{2} \mathrm{~S}$, and even $\mathrm{O}_{2}$ (Keil et al. 1980; Mallach and Schmidt 1980; see also Ettwig et al. 2010). To obtain data for the pressure that builds up in carcasses in different stages of bloating, intra-abdominal pressures were measured in 100 human corpses at the Institut 

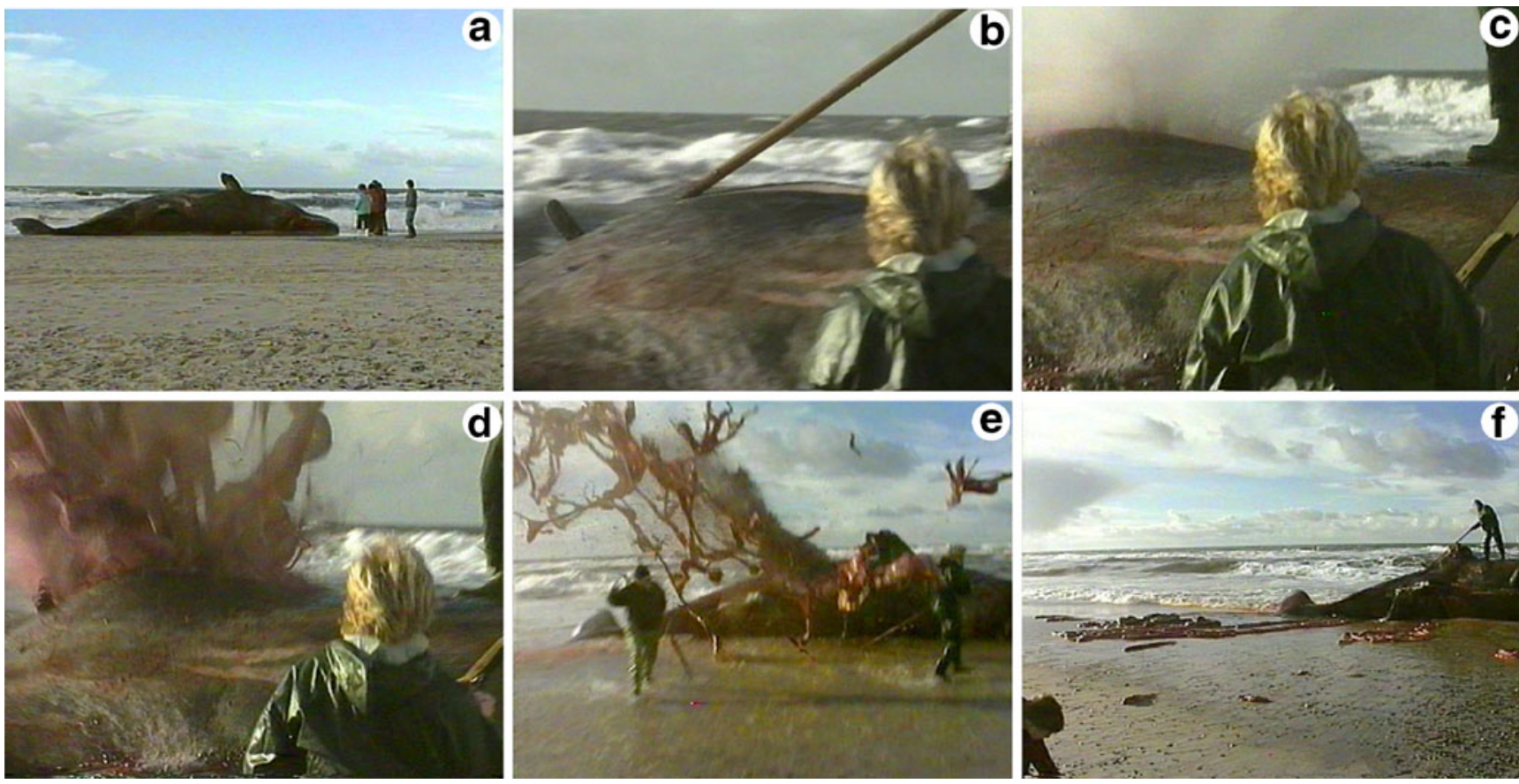

Fig. 2 Improper sectioning of a stranded whale carcass bloated by putrefaction gases at the beach of Nymindegab/ Denmark; body liquids and parts of the intestinal tract erupt violently from the body cavity (Krarup 1990; image by courtesy of TV/Midt-Vest)

für Forensische Medizin Frankfurt am Main in 2004 (Bux et al. 2004). The manometer (C9557 Pressure Meter; Comark, Hertfordshire, UK) was introduced into the abdominal cavity in the vicinity of the umbilicus by means of an anasarca trocar. The intraabdominal pressures did not exceed 0.035 bar (Fig. 3). This agrees with the pressures which were measured
Fig. 3 Relationship between effective intra-abdominal pressures and bloated stages in 100 human corpses (measured between January 1 and August 30, 2004). a Intraabdominal pressures at no (light grey bars) or mild (dark grey bars) visible inflation. Intra-abdominal pressures lower than atmospheric pressures are due to postmortem cooling of the corpses. b Intraabdominal pressures at moderate (light grey bars) or strong (dark grey bars) visible inflation. The range of intraabdominal pressures due to bloating by putrefaction gas is comparable to the pressures used in laparoscopic surgery (Abu-Rafea et al. 2006) a

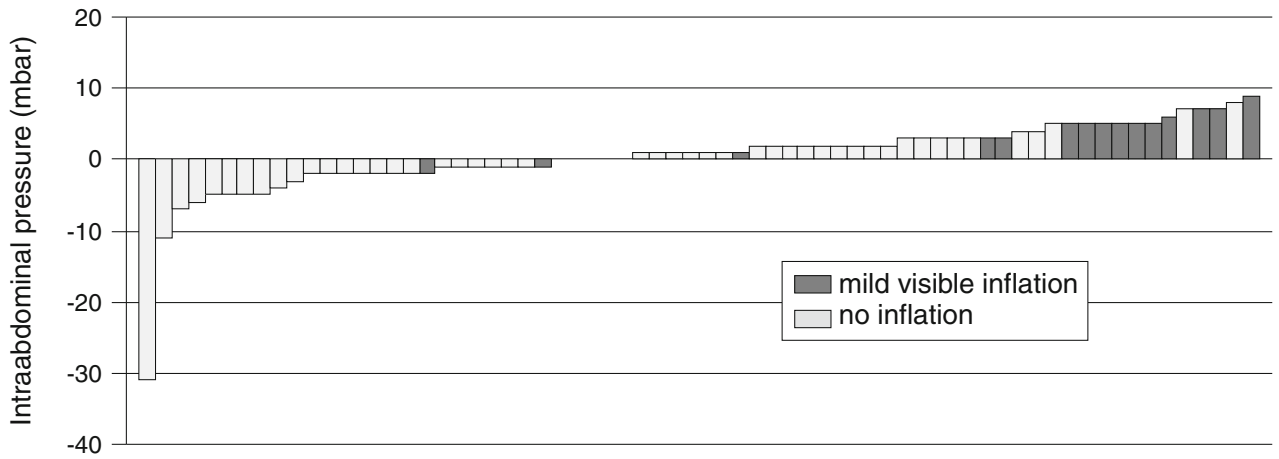

b

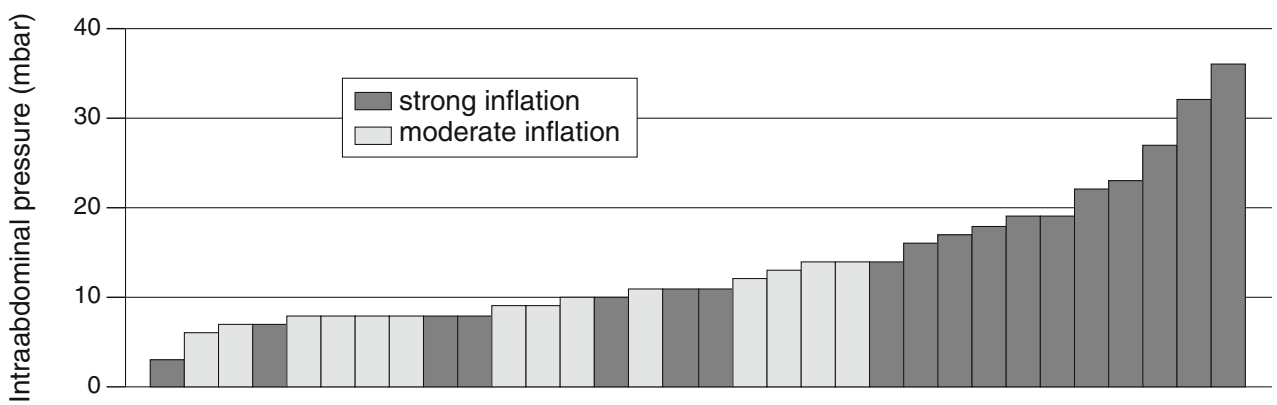

Cases 
by Fallani (1961) in human dead bodies. In goat carcasses, however, pressures up to 0.079 bar have been recorded (Li et al. 2003). These pressure values correspond to submersion depth in water of 0.35 and $0.79 \mathrm{~m}$. In the case of ichthyosaur carcasses that sank to the bottom of the Toarcian epeiric sea in Europe, potential hydrostatic pressures corresponding to a water depth of 50-150 m would reach 5-15 bar (Boyle's law; e.g., Haglund and Sorg 2002; Toklu et al. 2006; Tomita 1975). It is highly unlikely that intraabdominal pressures in the most common European ichthyosaur Stenopterygius quadriscissus (which usually attained 1.5-2.9 $\mathrm{m}$ in length; e.g., von Huene 1922; McGowan and Motani 2003) exceeded these values, and therefore, "carcass explosion" was impossible in greater water depths, close to or at the water surface. This appears even more unlikely because ichthyosaur fetuses are commonly found directly adjacent to the carcass of their mother in calculated water depths of 50-150 m (Fig. 1; Böttcher 1990; Hofmann 1958; Röhl et al. 2001), where such explosions are physically impossible.

Subsequently, we present two models explaining disarticulation of ichthyosaur skeletons of the Posidonienschiefer Formation. The burial depth of the carcass $(0-100 \%$ covered by sediment) plays an important role. This is especially true since the palaeoenvironment of the Posidonienschiefer Formation was neither entirely nor continuously anoxic (e.g., Kauffman 1981; Röhl et al. 2001; Röhl and Schmid-Röhl 2005).

\section{Effects of sediment compaction and currents}

Even in an oxygen-deficient environment, preservation potential of carcasses of marine tetrapods depends on burial depth (Hofmann 1958; Martill 1993). Organic-rich mudrocks such as the Early Jurassic Posidonienschiefer Formation exhibit a high initial porosity. During some time intervals, the topmost decimetres of the sediment were probably nearly fluid (="soupy substrate"; Hofmann 1958; Martill 1993; Röhl et al. 2001). The physical properties of such "soupy substrates" enabled ichthyosaur carcasses to sink into the sediment partially or entirely [e.g., Hofmann 1958; Martill 1993; Schimmelmann et al. 1994; Smith and Wuttke (2012, this issue), however, critically evaluate this taphonomic scenario of embedding of ichthyosaur carcasses]. Afterwards, the sediment was compacted by over $90 \%$ due to burial, causing intense brittle and "plastic" deformation of the skeleton parts (Einsele and Mosebach 1955; Hofmann 1958; Martill 1993) unless embedded in early diagenetic concretions (Keller 1992; Wetzel and Reisdorf 2007). The most intense deformation during compaction occurred in the thorax, causing the ribs to depart from their original arrangement and, as documented in some ichthyosaur fossils, from phosphatized or pyritized soft part remains (e.g., the stomach) near the abdominal and cloacal regions (Hofmann 1958; Keller
1976). These phenomena resemble injuries of an originally intact body characteristic of "crush/traumatic asphyxia" (e.g., Byard et al. 2006; Machel 1996), and this type of preservation contradicts explosion.

Organic-rich, muddy sediments like the Posidonienschiefer Formation are stated to accumulate mainly under prevailing tranquil conditions (e.g., Seilacher 1982). Evidence for weak to moderate currents, however, can be encountered in nearly all levels of the Posidonienschiefer Formation, indicating fluctuations in the depositional environment (Kauffman 1981; Röhl and Schmid-Röhl 2005; Schieber et al. 2007). Indeed, recent experiments show that such mud can be deposited from currents moving at $0.1-0.26 \mathrm{~m} / \mathrm{s}$ (Schieber et al. 2007). The erosion of such cohesive sediments requires high current velocities, depending on the degree of consolidation because of the electrostatic forces between particles (Sundborg 1956). Bacteria-particle interactions at the sediment surface might also increase the resistance against erosion (Black et al. 2003; Röhl et al. 2001; Widdel 1988). The low net sedimentation rate of the Posidonienschiefer Formation of $4 \mathrm{~mm} / 1,000$ years (calculated for compacted sediments; Röhl et al. 2001) and the high compressibility of such sediments might have favored dewatering of an initially "soupy substrate" (e.g., Bernhard et al. 2003; Wetzel 1990). Flumeexperiments with human and animal bones (density of dry and wet bones is usually below 2.65; Blob 1997; de Ricqlès and de Buffrénil 2001; Lam et al. 2003) revealed that bones of the thorax and the appendages begin to move at current velocities as low as 0.2-0.4 m/s (e.g., Blob 1997; Boaz and Behrensmeyer 1976; Coard 1999; Fernández-Jalvo and Andrews 2003). Such currents have been postulated for the shallow marine Early Toarcian epeiric sea (e.g., Hofmann 1958; Kauffman 1981; Martill 1993; Röhl and Schmid-Röhl 2005). The histology of ichthyosaur bones displays some convergences to Recent cetacean bones, which possess a lower density than land tetrapods (de Buffrénil et al. 1986; de Ricqlès and de Buffrénil 2001; Maas 2002). A further density decrease might have been caused by decay, microbial activity, and bone diagenesis (Arnaud et al. 1980; Fujiwara et al. 2007; Glover et al. 2005; Kiel 2008; Meyer 1991; Smith and Baco 2003). Thus, there was a real potential for transport of ichthyosaur bones by water currents.

All these factors make it highly probable that currents moved bones on the seafloor without eroding mud. This deduction is supported by the fact that $90 \%$ of all ichthyosaur specimens are disarticulated (Hauff 1921). The arrangement of ichthyosaur skeletal remains documents that the carcass was not or incompletely embedded in sediment for a considerable time (physical properties of the topmost decimetres of the seabottom prevented carcasses from being embedded entirely). Under these conditions, soft-tissues initially decomposed, causing the loss of connectivity of the skeletal elements, and the carcass eventually collapsed gravitationally (Hofmann 
1958; Martill 1993; Reisdorf and Wuttke 2012, this issue). Thoracic elements were most strongly affected by currents because they were usually exposed furthest above the ground and experienced highest current velocities. It is also conceivable that larger Metazoan scavengers played an additional role in the disarticulation and transport of skeletal elements (e.g., Kauffman 1981; Martill 1993; von Huene 1922), but the processes discussed above are of greater importance in a predominantly oxygen-deficient environment.

\section{Sink or float?}

The density of the ichthyosaur body and other aquatic lungbreathing tetrapods plays a crucial role in the potential to sink or float. Today, no Recent reptiles are known which can be considered as closely related to ichthyosaurs, especially with respect to anatomical and physiological characteristics. Therefore, Recent (facultatively) aquatic reptiles are only of limited use for such comparisons (e.g., Wade 1984). By contrast, Recent cetaceans (e.g., de Ricqlès and de Buffrénil 2001; Ridgway 2002; Sekiguchi and Kohshima 2003; Staunton 2005; Taylor 2000; Williams et al. 2000) may serve as a morphological and ecological model to reconstruct the postmortem fate of ichthyosaurs. With the exception of the species Eubalaena glacialis and Physeter macrocephalus, cetaceans have a density slightly higher than that of seawater (e.g., Butterworth 2005; Schäfer 1972; Shevill et al. 1967; Smith 2007a, b; Tønnessen and Johnsen 1982). E. glacialis and P. macrocephalus are relatively slow-swimming whales and the only species which usually does not sink after having been shot by whalers (Braham and Rice 1984; Gosho et al. 1984; Nowacek et al. 2001). [Jurassic Ichthyosaurs are usually considered to have been the fastest sustained swimmers of the Mesozoic seas (e.g., Lingham-Soliar and Wesley-Smith 2008) and thus seem also likely to have been negatively buoyant.] The low density of the bodies of these species, the socalled "right whales", is caused by an extraordinarily high content of oil and fat (e.g., Glover et al. 2008; Gosho et al. 1984; Kemp et al. 2006; Slijper 1962). Other "right whales" (e.g. Balaenoptera musculus) may float after death only when caught by "Electrical Whaling"; paralyzed thoracic musculature apparently accounts for this phenomenon (Øen 1983).

Odontoceti might also become positively buoyant when the lungs are almost completely or entirely filled by air (e.g., Ridgway et al. 1969; Slijper 1962). Among living and etiologically unconditioned cetaceans, the lung volume never gets used exhaustively (Wartzok 2002). The respiration physiology of mammals, however, is significantly different from that of Recent reptiles; most of the latter exhale actively and inhale passively (Carrier and Farmer 2000; Perry 1983).
This line of reasoning suggests that even if inhalation in ichthyosaurs was passive as in Recent reptiles, they would still have been negatively buoyant (e.g., Hogler 1992; Wade 1984) and sunk immediately after death, unless the lungs were filled with air to an abnormal degree (e.g., pulmonary emphysema; Siebert et al. 2001; Slijper 1962; Ridgway et al. 1969; Fig. 4).

Incipient decomposition at the seafloor causes a reduction in carcass density. How far gaseous putrefaction products develop in the carcass, and whether they are dissolved or bound within the soft-tissues and body liquids, depends mainly on the local hydrostatic pressure and temperature (Allison et al. 1991; Dickson et al. 2011; Hofmann 1958; Lucas et al. 2002; McLellan et al. 1995; Smith and Baco 2003; Tomita 1975, 1976; Wasmund 1935; Zangerl and Richardson 1963). All main components of the putrefaction gas $\left(\mathrm{N}_{2}, \mathrm{H}_{2}, \mathrm{O}_{2}\right.$; possibly also $\left.\mathrm{CH}_{4}\right)$ except for the $\mathrm{CO}_{2}$ share a low solubility at temperatures below $4^{\circ} \mathrm{C}$ and moderate pressures $\left(\mathrm{O}_{2}>\mathrm{N}_{2}>\mathrm{CH}_{4}>\mathrm{H}_{2}\right.$; Ashcroft 2002: 59; Mallach and Schmidt 1980; Ramsey 1962; Shafer and Zare 1991; Weiss and Price 1989) and tend to increase buoyancy by forming bubbles (Dumser and Türkay 2008; Mueller 1953; Tomita 1975). It depends on the integrity of the skin and the digestive tract whether these gases can accumulate inside the carcass (beneath the skin and in the body cavities; Anderson and Hobischak 2004; Dumser and Türkay 2008; Haglund 1993; Schäfer 1972; Smith and Baco 2003; Thali et al. 2003).

In shallow water and at temperatures above $4^{\circ} \mathrm{C}$, it is very likely that putrefaction gases would cause carcasses to surface and drift (presuming that they are not covered by sediment; Haberda 1895; Hofmann 1958; Moreno et al. 1992; Petrik et al. 2004; Sorg et al. 1997; Tomita 1975, 1976; Wasmund 1935). Drifting at the water surface, sometimes over months and long distances, carcasses decompose gradually (Giertsen and Morild 1989; Haglund 1993; Schäfer 1972; Smith 2007a; Tomita 1975, 1976; Wild 1978).

Empirical data on the hydrostatic pressure needed to keep a carcass at the sediment surface are available for cetaceans, various terrestrial tetrapods such as humans, mice, and domestic pigs, and different freshwater fish (e.g., Allison et al. 1991; Anderson and Hobischak 2004; Berg 2004; Elder and Smith 1988; Esperante et al. 2008; Moreno et al. 1992; Smith 2007a; Tomita 1975, 1976; Tønnessen and Johnsen 1982). These studies reveal that higher hydrostatic pressures are required to suppress the rise of carcasses of larger dimensions compared to smaller carcasses (e.g., Barton and Wilson 2005; Tomita 1975, 1976; see also Kemp 2001). Apparently, taxonomy does not play a major role in this respect, but physics does (Tomita 1975).

In marine environments, Recent cetaceans and human carcasses may rise from water depths up to $50 \mathrm{~m}$, but never from below $100 \mathrm{~m}$ (Tomita 1975, 1976; Tønnessen and Johnsen 1982). The above-mentioned water depth estimate 


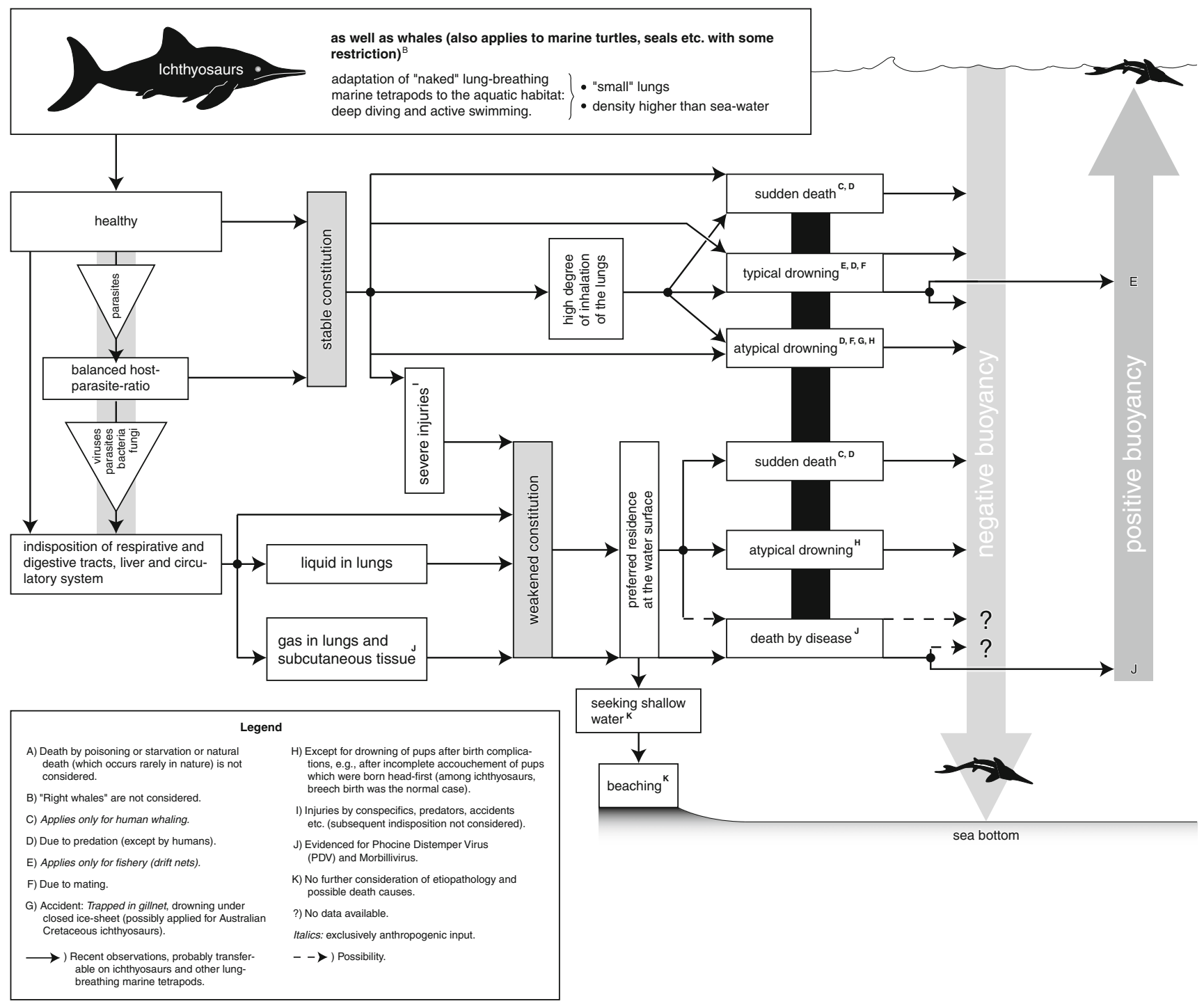

Fig. 4 Peri- and postmortem behavior of marine tetrapods without buoyancy-increasing body fat, oil, hair or feathers in the pelagic realm (modified after Hänggi and Reisdorf 2007; references in Reisdorf 2007)

of the "Posidonienschiefer Formation sea" in southern Germany of 50-150 m (Röhl et al. 2001) matches the physical requirements to keep an ichthyosaur carcass on the seafloor. In the case of nearly complete ichthyosaur skeletons, it is very likely that the carcass was entombed close to the place of death because of the short settling time.

\section{Skeleton preservation as a sea-level proxy?}

The taphonomy of lung-breathing tetrapods depends on water depth and, thus, can be used as palaeobathymetrical proxy (cf. Allison et al. 1991). Early Jurassic ichthyosaur remains display recurring taphonomic patterns which can be grouped into three preservation categories: (1) articulated skeletons, (2) disarticulated skeletons, and (3) isolated bones (e.g., Martill 1986, 1993; isolated body parts of predated animals which sank towards the seafloor are not considered in the subsequent discussion; e.g., Böttcher 1989; Martill 1993; Taylor 2001).

Articulated skeletons are equally abundant and welldocumented throughout the Early Toarcian; for instance, $>3000$ more or less articulated specimens are known just from the Holzmaden area in Germany (Martill 1993; McGowan and Motani 2003). These articulated skeletons are not included in this analysis because these carcasses were apparently largely or completely embedded 
in the sediment immediately after grounding while sinking into the "soupy substrate" (Hofmann 1958; Martill 1993; but see Smith and Wuttke 2012, this issue). Adhesion and sediment weight prevented the carcass from surfacing even when putrefaction gases developed sufficiently to lift the carcass (Hofmann 1958; see also Piccard 1961). Additionally, they were protected against Metazoan scavengers (Hofmann 1958) or bottom currents, i.e. the carcasses could not be realigned after their deposition.

Disarticulated skeletons are mainly found in sediments deposited during times of eustatic sea-level rise (=transgressive cycles; e.g., de Graciansky et al. 1998; Hallam 2001) under oxygen-depleted conditions (Hauff 1921; Röhl et al. 2001). Such skeletons were probably not or not completely covered by sediment for a prolonged timespan or they were secondarily exhumed (e.g., Hofmann 1958; Kauffman 1981; Martill 1993). Apparently, rising of the carcasses was prevented by hydrostatic pressure and/or partial sediment cover (Allison et al. 1991; Hofmann 1958; Tomita 1975, 1976). Speculatively, an overgrowth by microbial mats or other organisms might have had the potential to prevent the carcass from refloatation to the water surface. However, the remarkable completeness of isolated parts of a skeleton found in spatial proximity rules out strong bottom currents.

Isolated bones, scarcity or absence of ichthyosaur fragments result from times of eustatic sea-level fall (=regressive cycles; e.g., de Graciansky et al. 1998; Hallam 2001). Many carcasses surfaced because of the low hydrostatic pressure which allowed putrefaction gases to develop. These skeletons disintegrated while floating (e.g., Hofmann 1958; Martill 1986, 1993). Such isolated bones possibly underwent a further maceration up to complete disintegration.

The "Ichthyosaur Corpse Curve" (ICC; Fig. 5) summarizes the frequency of different modes of ichthyosaur preservation in Central Europe during the Lower Jurassic. The poor correlation of the ichthyosaur record of the Hettangian with the sealevel curve of Hallam $(1988,2001)$ may be explained by the generally still low sea-level of this interval. The "Ichthyosaur Corpse Curves" are based on data from England, Germany, and Switzerland for which a reasonable amount of well-

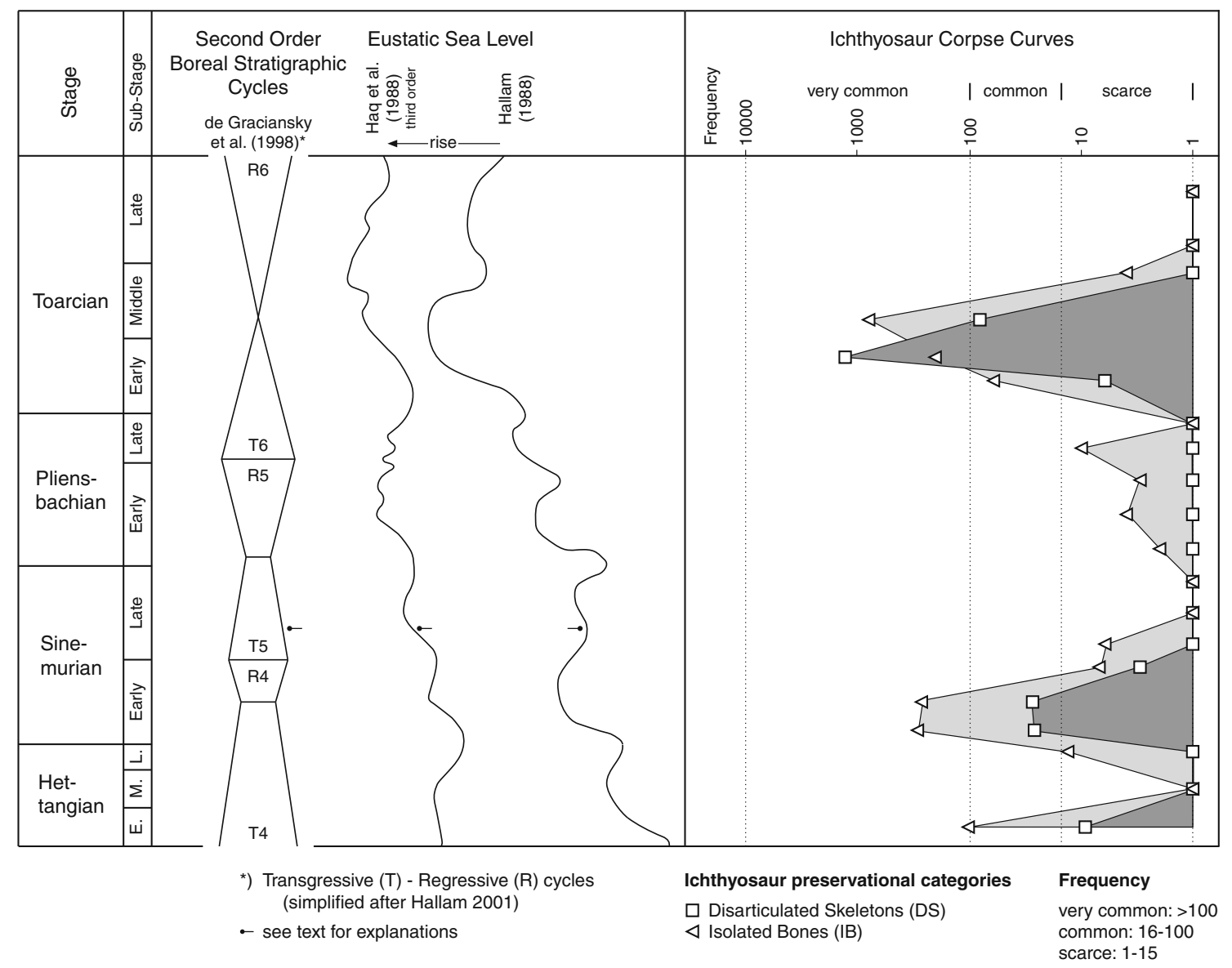

Fig. 5 Taphonomy of Early Jurassic ichthyosaurs from northwestern and central Europe compared to eustatic sea-level curves. Ichthyosaur taphonomy appears to reflect eustatic sea-level changes. A rising or relatively high eustatic sea-level sensu Hallam (2001) appears to favor rich occurrences of ichthyosaurs (literature data and estimates; see Table 1). At times of low or falling sea-level or low-amplitude rise, ichthyosaur remains are scarce, and preservation of single bones prevails (see Table 1 and main text; see also Hesselbo and Palmer 1992) 
documented ichthyosaur remains over a longer time interval is available. These occurrences are plotted on a logarithmic scale to give an impression of the three abundance categories. Absence of fossils was set to one occurrence to make them displayable on the logarithmic scale. Due to the unsatisfying documentation of ichthyosaur finds especially in the nineteenth century, partially caused by a focus on articulated skeletons, we had to guess the number of occurrences in several cases, especially since we chose a temporal resolution on ammonite-zone level. The numbers of disarticulated skeletons (DS) and isolated bones (IB) of the "Ichthyosaur Corpse Curves" represent an estimate of the minimum unless precise numbers from the literature or collections were available. In some cases, we estimated some numbers of IB based on the usual ratio of DS to IB of $1: 10$ to $1: 100$. Accordingly, the amount of DS in British fossillagerstätten is based on the number of occurrences of articulated skeletons. The abundance of disarticulated ichthyosaur-remains as shown by the DS:IB ratio thus reflects the fossil record in the Lower Jurassic ammonite zones of Great Britain, southern Germany and northern Switzerland (Table 1).

Table 1 These data on the occurrences and abundances of preservational modes (disarticulated skeletons $D S$; and isolated bones $I B$ ) were obtained from museum collection counts (Paläontologische Forschungs-, Lehrund Schausammlung am Institut für Geowissenschaften Universität Tübingen, Sammlung am Staatlichen Museum für Naturkunde Stuttgart) and from the literature (Altmann 1965; Benton and Taylor 1984; Benton
Stratigraphical resolution is in the range of a few million years spanning 3rd order cycles of Haq et al. (1988) or 2nd order cycles of Hallam (e.g., de Graciansky et al. 1998; Hallam 2001). It appears that ichthyosaur skeletal remains are most abundant in sediments of transgressive cycles and rare in sediments of regressive cycles. Cycle T5 of Haq et al. (e.g., de Graciansky et al. 1998) is poor in ichthyosaur remains, but, by contrast, this interval corresponds to a phase of falling sealevel of Hallam (e.g., Hallam 2001; Fig. 5).

\section{Conclusions and significance}

1. According to our measurements and deductions, it is impossible that skeletons of vertebrates become disarticulated with their bones being scattered over a certain area exclusively by the release of putrefaction gases under hydrostatic or atmospheric pressures.

2. There is ample evidence that ichthyosaurs and most other lung-breathing marine tetrapods of comparable mode of life were negatively buoyant. This is

and Spencer 1995; Berckhemer 1938; Dean et al. 1961; Delair 1960; Fraas 1891; Hauff 1921; von Huene 1922, 1931; Knitter and Ohmert 1983; Maisch 1999; Maisch and Reisdorf 2006; Maisch et al. 2008; Martin et al. 1986; McGowan 1978; McGowan and Motani 2003; Meyer and Furrer 1995; Pratje 1922; Quenstedt 1858; Reiff 1935; Reisdorf et al. 2011; Schieber 1936); for a comment of the quality of the data, see text

\begin{tabular}{|c|c|c|c|c|c|c|c|c|c|}
\hline \multirow{2}{*}{$\begin{array}{l}\text { Ammonite zonation sensu } \\
\text { Dean et al. (1961) }\end{array}$} & \multirow[t]{2}{*}{ Stages } & \multicolumn{2}{|c|}{ Great Britain } & \multicolumn{2}{|c|}{ Germany } & \multicolumn{2}{|c|}{ Switzerland } & \multirow[t]{2}{*}{ Sum DS } & \multirow[t]{2}{*}{ Sum IB } \\
\hline & & DS & IB & DS & IB & DS & IB & & \\
\hline levesquei & Toarcian & 0 & 0 & 0 & 1 & 0 & 0 & 0 & 1 \\
\hline thouarsense & & 0 & 1 & 0 & 0 & 0 & 0 & 0 & 1 \\
\hline variabilis & & 0 & 0 & 0 & 4 & 0 & 0 & 0 & 4 \\
\hline bifrons & & 61 & 610 & 18 & 180 & 0 & 0 & 79 & 790 \\
\hline falcifer & & 6 & 60 & 1,295 & 130 & 2 & 11 & 1,303 & 201 \\
\hline tenuicostatum & & 0 & 0 & 6 & 60 & 0 & 0 & 6 & 60 \\
\hline spinatum & Pliensbachian & 0 & 0 & 0 & 1 & 0 & 0 & 0 & 1 \\
\hline margaritatus & & 0 & 0 & 0 & 10 & 0 & 0 & 0 & 10 \\
\hline davoei & & 0 & 0 & 0 & 3 & 0 & 0 & 0 & 3 \\
\hline ibex & & 0 & 0 & 1 & 4 & 0 & 0 & 1 & 4 \\
\hline jamesoni & & 0 & 1 & 0 & 0 & 0 & 1 & 0 & 2 \\
\hline raricostatum & Sinemurian & 0 & 1 & 0 & 0 & 0 & 0 & 0 & 1 \\
\hline oxynotum & & 0 & 0 & 0 & 0 & 0 & 0 & 0 & 0 \\
\hline obtusum & & 1 & 6 & 0 & 0 & 0 & 0 & 1 & 6 \\
\hline turneri & & 0 & 1 & 3 & 6 & 0 & 0 & 3 & 7 \\
\hline semicostatum & & 25 & 250 & 1 & 6 & 1 & 11 & 27 & 267 \\
\hline bucklandi & & 25 & 250 & 1 & 35 & 0 & 0 & 26 & 285 \\
\hline angulata & Hettangian & 0 & 0 & 0 & 11 & 0 & 2 & 0 & 13 \\
\hline liasicus & & 0 & 0 & 0 & 1 & 0 & 0 & 0 & 1 \\
\hline planorbis & & 9 & 90 & 0 & 12 & 0 & 0 & 9 & 102 \\
\hline
\end{tabular}


corroborated by the fact that even the density of some of the lightest Recent cetaceans (e.g., harbor porpoise Phocoena phocoena) is higher than that previously assumed for the most common European ichthyosaur Stenopterygius (Kemp et al. 2006; McLellan et al. 2002; Motani 2001; Reisdorf 2007). Therefore, previous body mass calculations of ichthyosaur bodies, which presume a seawater density of the ichthyosaurs, are too low (Reisdorf 2007).

3. If an ichthyosaur body is assumed to have been negatively buoyant, locomotion models which assume that ichthyosaurs needed to overcome positive buoyancy when diving (e.g., Taylor 1987; McGowan 1992) require re-evaluation. Sleep behavior must also have been adapted for negative buoyancy: ichthyosaurs had to actively surface to respire, as do Cetaceans (e.g., Lyamin et al. 2006; Ridgway 2002; Staunton 2005; Wade 1984).

4. Most of the ichthyosaurs that were not killed by external forces died by drowning when rendered unable to surface, due to diseases, complications during pregnancy and the birth process, or old age (Kastelein et al. 1995; Knieriem and García Hartmann 2001; Reisdorf 2007; Shevill et al. 1967; Slijper 1962; Smith 2007a; Fig. 4). They subsequently sank. This theoretically opens the possibility to apply the "diatom-test" (e.g., Hürlimann et al. 2000) to ichthyosaurs, especially to Cretaceous representatives. These algae and other small particles (e.g., Knieriem and García Hartmann 2001; Möttönen and Nuutila 1977; Yoshimura et al. 1995) can be deposited in bones when lung-breathing vertebrates inhale water when drowning (but see also Kan 1973, and Koseki 1968). However, the possible occurrence of such a "fossil trap" has yet to be analysed.

5. Ichthyosaurs usually settled on the sea-floor without any density increase or buoyancy decrease except for the compression of the body as well as the compression (e.g., Hui 1975) and the dissolution of gas contained in the carcass (e.g., Haglund and Sorg 2002; Kemp 2001; Smith 2007a).

6. Buoyancy-increasing formation of putrefaction gases plays a crucial role with respect to the drift behaviour and fossilization of vertebrate carcasses in shallow marine (and lacustrine) depositional environments. A disarticulated skeleton with bones preserved in spatial proximity helps to estimate palaeobathymetry, because the hydrostatic pressure had to be sufficient to counteract the effects of gas formed by putrefaction (="Cartesian Diver Effect"). This is also important for the interpretation of marine (and lacustrine) fossillagerstätten (e.g., Beardmore et al. 2012, this issue; Buffetaut 1994; Elder and Smith 1988; Esperante et al. 2008;
Hofmann 1958; Hogler 1992; Mancuso and Marsicano 2008; Reisdorf and Wuttke 2012, this issue; Sander 1989; Smith and Wuttke 2012, this issue; Zangerl and Richardson 1963).

7. We suggest the use of the term "ichthyosaur fall" for more or less completely preserved ichthyosaur skeletons. This is in accordance with the established marine biological terms "nekton fall" and "whale fall" (e.g., Smith and Baco 2003), which describe carcasses or skeletons of nektonic organisms which sank through the water column to the seafloor.

8. We found that our newly constructed "Ichthyosaur Corpse Curves" for England, south-western Germany and Switzerland (Fig. 5) correlate well with the global sea-level curve of the Early Jurassic by Hallam (e.g., Hallam 2001), but do not match that of Haq et al. (1988) or de Graciansky et al. (1998). Additional uniformitarian taphonomic studies of modern marine lung-breathing vertebrates are necessary to improve "nekton falls" as a useful palaeobathymetric proxy.

9. Most of the outlined factors and mechanisms affecting the density and maceration of Recent cetaceans and ichthyosaurs in water can be generalised with respect to most lung-breathing marine vertebrates and various land-living tetrapods such as humans, at least with some minor modifications (e.g., Donoghue and Minnigerode 1977; Gray et al. 2007; Tomita 1975, 1976).

10. Our findings have implications for a number of today's environmental problems and the protection of species: The carcasses of many lung-breathing marine vertebrates, such as those of whales, cannot be observed because most of them will never surface or strand (e.g., Cassoff et al. 2011; Ford et al. 2000; Kirkwood et al. 1997; Moreno et al. 1992; Smith 2007a). Knowledge of postmortem hydrostatic pressure, temperature and scavenging rate conditions in Recent cetaceans and ichthyosaurs can serve as a model for human carcasses (Anderson and Hobischak 2004; Haglund 1993; Hood et al. 2003; Kahana et al. 1999; Moreno et al. 1992; Petrik et al. 2004; Schäfer 1972) and thus be applied to the retrieval of missing humans after disasters (e.g., tsunamis, heavy flooding, cyclones) and crimes from bodies of water (e.g., Blanco Pampin and Lopez-Abajo Rodriguez 2001; Tomita 1975, 1976; Tsokos and Byard 2011).

Acknowledgements We thank R. Allenbach, H. Benke, R. Böttcher, J.K. Broadrick, D. Flentje, M.C. Haff, J. Hermann, J. Hürlimann, T. Keller, F. Lörcher, S. Lutter, J.H. Modell, M.D. Pirie, K. Schneider, R. Schoch, Y. Song, B. Springmann, M. Stede, D. Trottenberg, M. Wuttke, J. Zopfi, Institut für Rechtsmedizin der Universität Basel and WWF Bremen for their input. D.M. Martill and an anonymous reviewer critically read the manuscript and made helpful suggestions. Two anonymous colleagues kindly reviewed an earlier 
version of this article. This research was supported by a grant from the Swiss National Science Foundation (to A.G.R. and A.W.) and Freiwillige Akademische Gesellschaft Basel (A.G.R.). All these contributions are gratefully acknowledged.

\section{References}

Abu-Rafea B, Vilos GA, Vilos AG, Hollett-Caines J, Al-Omran M (2006) Effect of body habitus and parity on insufflated $\mathrm{CO}_{2}$ volume at various intraabdominal pressures during laparoscopic access in women. J Mini Invas Gynecol 13:205-210

Allison PA, Smith CR, Kukert H, Deming JW, Bennett BA (1991) Deep-water taphonomy of vertebrate carcasses. a whale skeleton in the bathyal Santa Catalina Basin. Paleobiology 17:78-89

Altmann HJ (1965) Beiträge zur Kenntnis des Rhät-Lias-Grenzbereichs in Südwest-Deutschland. Dissertation, University of Tübingen

Anderson GS, Hobischak NR (2004) Decomposition of carrion in the marine environment in British Columbia, Canada. Int J Leg Med 118:206-209

Anonymous (2004) Rotting sperm whale spills its guts. Nature 427:478

Arnaud G, Arnaud S, Ascenzi A, Bonucci E, Graziani G (1980) On the problem of the preservation of human bone in sea-water. Int $\mathrm{J}$ Naut Archaeol Underw Expl 9:53-65

Ashcroft F (2002) Life at the extremes: the science of survival. University of California Press, Berkeley

Bajanowski T, West A, Brinkmann B (1998) Proof of fatal air embolism. Int J Leg Med 111:208-211

Barton DG, Wilson MVH (2005) Taphonomic variations in Eocene fishbearing varves at Horsefly, British Columbia, reveal 10000 years of environmental change. Can J Earth Sci 42:137-149

Beardmore SR, Orr PJ, Furrer H (2012) Float or sink: modelling the taphonomic pathway of marine crocodiles (Mesoeucrocodylia, Thalattosuchia) during the death-burial interval. In: Wuttke M, Reisdorf AG (eds) Taphonomic processes in terrestrial and marine environments. Palaeobio Palaeoenv 92(1). doi:10.1007/s12549011-0066-0

Benton MJ, Taylor MA (1984) Marine reptiles from the Upper Lias (Lower Toarcian, Lower Jurassic) of the Yorkshire coast. Proc Yorkshire Geol Soc 44:399-429

Benton MJ, Spencer PS (1995) Fossil Reptiles of Great Britain. Geol Conserv Rev Ser No. 10, Chapman and Hall, London

Berckhemer F (1938) Das Gebiß von Leptopterygius platyodon CONYB. Paleobiology 6:150-163

Berg S (2004) Todeszeitbestimmung in der spätpostmortalen Phase. In: Brinkmann B, Madea B (eds) Handbuch gerichtliche Medizin, Band 1. Springer, Berlin, pp 91-204

Bernhard JM, Visscher PT, Bowser SS (2003) Submillimeter life positions of bacteria, protists, and metazoans in laminated sediments of the Santa Barbara Basin. Limnol Oceanogr 48:813-828

Black KS, Peppe C, Gust G (2003) Erodibility of pelagic carbonate ooze in the northeast Atlantic. J Exp Mar Biol Ecol 285286:143-163

Blanco Pampin J, Lopez-Abajo Rodriguez BA (2001) Surprising drifting of bodies along the coast of Portugal and Spain. Leg Med (Tokyo) 3:177-182

Blob RW (1997) Relative hydrodynamic dispersal potentials of softshelled turtle elements: implications for interpreting skeletal sorting in assemblages of non-mammalian terrestrial vertebrates. Palaios 12:151-164

Boaz NT, Behrensmeyer AK (1976) Hominid taphonomy: transport of human skeletal parts in an artificial fluviatile environment. Am J Phys Anthropol 45:53-60
Bonhotal J, Harrison E, Schwarz M (2006) Evaluating Pathogen Destruction in Road Kill Composting. Biocycle 47:49-51

Bloos G, Dietl G, Schweigert G (2005) Der Jura Süddeutschlands in der Stratigraphischen Tabelle von Deutschland 2002. Newslett Stratigr 41:263-277

Böttcher R (1989) Über die Nahrung eines Leptopterygius (Ichthyosauria, Reptilia) aus dem süddeutschen Posidonienschiefer (Unterer Jura) mit Bemerkungen über den Magen der Ichthyosaurier. Stuttg Beitr Naturkd B 155:1-19

Böttcher R (1990) Neue Erkenntnisse über die Fortpflanzungsbiologie der Ichthyosaurier. Stuttg Beitr Naturkd B 164:1-51

Bozzano A, Sardà F (2002) Fishery discard consumption rate and scavenging activity in the northwestern Mediterranean Sea. ICES J Mar Sci 59:15-28

Braham HW, Rice DW (1984) The Right Whale, Balaena glacialis. Mar Fish Rev 46:38-44

Britton JC, Morton B (1994) Marine carrion and scavengers. Oceanogr Mar Biol 32:369-434

Buffetaut E (1994) The significance of dinosaur remains in marine sediments: an investigation based on the French record. Berliner Geowiss Abh E 13:125-133

de Buffrénil V, Sire J-Y, Schoevaert D (1986) Comparaison de la structure et du volume squelettiques entre un delphinidé (Delphinus delphis L.) et un mammifère terrestre (Panthera leo L.). Can J Zool 64:1750-1756

Butterworth A (2005) Death at sea - when is a whale dead? Vet J 169:5-6

Bux R, Reisdorf A, Ramsthaler F (2004) Did the Ichthyosaurs explode? - A forensic-medical contribution to the Taphonomy of Ichthyosaurs in Bituminous Shales. Baltik Medico-Legal Association, Abstracts of the 5th BMLA Congress, October 6.-9. 2004, Saint-Petersburg, p 69

Byard RW, Wick R, Simpson E, Gilbert JD (2006) The pathological features and circumstances of death of lethal crush/traumatic asphyxia in adults - a 25-year study. Forensic Sci Int 159:200-205

Cassoff RM, Moore KM, McLellan WA, Barco SG, Rotstein DS, Moore MJ (2011) Lethal entanglement in baleen whales. Diseas Aquat Org 96:175-185

Carrier DR, Farmer CG (2000) The Integration of Ventilation and Locomotion in Archosaurs. Am Zool 40:87-100

Coard R (1999) One bone, two bones, wet bones, dry bones: transport potentials under experimental conditions. J Archaeol Sci 26:1369-1375

Cruickshank ARI, Fordyce RE (2002) A new marine reptile (Sauropterygia) from New Zealand: Further evidence for a Late Cretaceous austral radiation of cryptoclidid plesiosaurs. Palaeontol J 45:557-575

Daldrup T, Huckenbeck W (1984) Bedeutung des Fäulnisbakteriums Clostridium sordellii für die Leichenaltersbestimmung. Z Rechtsmed 92:121-125

Dahlgren TG, Wiklund H, Källström B, Lundälv T, Smith CR, Glover AG (2006) A shallow-water whale-fall experiment in the north Atlantic. Cah Biol Mar 47:385-389

Davis JH (1986) Bodies found in the water: an investigate approach. Am J Forensic Med Pathol 7:291-297

Dean WT, Donovan DT, Howarth MK (1961) The Liassic ammonite zones and subzones of the north-west European province. Bull $\mathrm{Br}$ Mus Nat Hist Geol 4:435-505

Delair JB (1960) The Mesozoic reptiles of Dorset: Part Three Conclusion. Proc Dorset Nat Hist Archaeol Soc 1959(79):59-85

Dickson GC, Poulter RTM, Maas EW, Probert PK, Kieser JA (2011) Marine bacterial succession as a potential indicator of postmortem submersion interval. Forensic Sci Int 209:1-10

Dollo L (1907) L'Audition chez les Ichthyosauriens. Bull Soc Belge Géol Paléontol Hydrol 21:157-163

Donoghue ER, Minnigerode SC (1977) Human body buoyancy: a study of 98 men. J Forensic Sci 22:573-579 
Dumser TK, Türkay M (2008) Postmortem Changes of Human Bodies on the Bathyal Sea Floor - Two Cases of Aircraft Accidents Above the Open Sea. J Forensic Sci 53:1049-1052

Einsele G, Mosebach R (1955) Zur Petrographie, Fossilerhaltung und Entstehung der Gesteine des Posidonienschiefers im Schwäbischen Jura. N Jb Geol Paläont Abh 101:319-430

Eisele R (1969) Das postmortale Eindringen von Flüssigkeit in die Lungen und den Magen-Darmkanal beim Aufenthalt unter Wasser. Dissertation, University of Düsseldorf

Elder RL, Smith GR (1988) Fish taphonomy and environmental inference in paleolimnology. Palaeogeogr Palaeoclimatol Palaeoecol 62: 577-592

Esperante R, Brand L, Nick KE, Poma O, Urbina M (2008) Exceptional occurrence of fossil baleen in shallow marine sediments of the Neogene Pisco Formation, Southern Peru. Palaeogeogr Palaeoclimatol Palaeoecol 257:344-360

Ettwig KF, Butler MK, Le Paslier D et al (2010) Nitrite-driven anaerobic methane oxidation by oxygenic bacteria. Nature 464 : 543-548

Fallani M (1961) Contributo allo studio della circolazione ematica post-mortale. Minerva Medicoleg (Torino) 81:108-115

Fernández-Jalvo Y, Andrews P (2003) Experimental Effects of Water Abrasion on Bone Fragments. J Taph 1:145-161

Fiedler S, Graw M (2003) Decomposition of buried corpses, with special reference to the formation of adipocere. Naturwiss 90:291-300

Ford JKB, Ellis GM, Balcomb KC (2000) Killer whales: the natural history and genealogy of Orcinus orca in British Columbia and Washington, 2nd edn. UBC Press, Vancouver

Fraas E (1891) Die Ichthyosaurier der süddeutschen Trias- und Jura-Ablagerungen. Laupp, Tübingen

Fröbisch NB, Sander M, Rieppel O (2006) A new species of Cymbospondylus (Diapsida, Ichthyosauria) from the Middle Triassic of Nevada and a re-evaluation of the skull osteology of the genus. Zool J Linn Soc 147:515-538

Fujiwara Y, Kawato M, Yamamoto T, Yamanaka T, Sato-Okoshi W, Noda C, Tsuchida S, Komai T, Cubelio SS, Sasaki T, Jacobsen K, Kubokawa K, Fujikura K, Maruyama T, Furushima Y, Okoshi K, Miyake H, Miyazaki M, Nogi Y, Yatabe A, Okutani T (2007) Three-year investigations into sperm whale-fall ecosystems in Japan. Mar Ecol 28:219-232

Giertsen JC, Morild I (1989) Seafaring bodies. Am J Forensic Med Pathol 10:25-27

Glover AG, Källström B, Smith CR, Dahlgren TG (2005) World-wide whale worms? A new species of Osedax from the shallow north Atlantic. Proc R Soc Lond B 272:2587-2592

Glover AG, Kemp KM, Smith CR, Dahlgren TG (2008) Comment "On the role of bone-eating worms in the degradation of marine vertebrate remains". Proc R Soc Lond B 275:1959-1961

Gosho ME, Rice DW, Breiwick JM (1984) The Sperm Whale, Physeter macrocephalus. Mar Fish Rev 46:54-64

de Graciansky PC, Dardeau G, Dommergues JL, Durlet C, Marchand D, Dumont T, Hesselbo SP, Jacquin T, Goggin V, Meister C, Mouterde R, Rey J, Vail PR (1998) Ammonite Biostratigraphic Correlation and Early Jurassic Sequence Stratigraphy in France: Comparisons with some U.K. Section. SEPM Soc Sed Geol Spec Publ 60:583-622

Gradstein F, Ogg J, Smith A (2004) A Geologic Time Scale 2004. Cambridge University Press, Cambridge

Gray N-M, Kainec K, Madar S, Tomko L, Wolfe S (2007) Sink or swim? Bone density as a mechanism for buoyancy control in early cetaceans: The Anatomical Record. Adv Integr Anat Evol Biol 290:638-653

Haberda A (1895) Einiges über Wasserleichen. Vierteljahresschr gerichtl Med öff Sanitätsw (Dritte Folge) 9:95-110

Haglund WD (1993) Disappearance of soft tissue and the disarticulation of human remains from aqueous environments. $\mathrm{J}$ Forensic Sci 8:806-815
Haglund WD, Sorg MH (2002) Human remains in water environments. In: Haglund WD, Sorg MH (eds) Advances in forensic taphonomy method, theory and archeological perspectives. CRC Press, Boca Raton, pp 201-218

Hallam A (1988) A re-evaluation of the Jurassic eustasy in the light of new data and the revised Exxon curve. SEPM Soc Sed Geol Spec Publ 42:261-273

Hallam A (2001) A review of the broad pattern of Jurassic sea-level changes and their possible causes in the light of current knowledge. Palaeogeogr Palaeoclimatol Palaeoecol 167:23-37

Hänggi H, Reisdorf AG (2007) Der Ichthyosaurier vom Hauensteiner Nebelmeer - Wie eine Kopflandung die Wissenschaft Kopf stehen lässt. Mitt Natforsch Ges Kanton Solothurn 40:7-22

Haq BU, Hardenbol J, Vail PR (1988) Mesozoic and Cenozoic chronostratigraphy and cycles of sea-level change. SEPM Spec Publ 42:71-108

Hauff B (1921) Untersuchungen der Fossilfundstätten von Holzmaden im Posidonienschiefer des oberen Lias Württembergs. Palaeontographica $64: 1-42$

Hesselbo SP, Palmer TJ (1992) Reworked early diagnetic concretions and the bioerosional origin of a regional discontinuity within marine mudstones. Sedimentology 39:1045-1065

Hofmann J (1958) Einbettung und Zerfall der Ichthyosaurier im Lias von Holzmaden. Meyniana 6:10-55

Hogler JA (1992) Taphonomy and paleoecology of Shonisaurus popularis (Reptilia: Ichthyosauria). Palaios 7:108-117

Hood C, Daoust P, Lien J, Richter C (2003) An experimental study of postmortem ocular fluid and core temperature analysis in incidentally captured harbour porpoise (Phocoena phocoena). North Atlantic Marine Mammal Commission (NAMMCO). Sci Publ 5:229-242

von Huene F (1922) Die Ichthyosaurier des Lias und ihre Zusammenhänge. Gebrüder Bornträger, Berlin

von Huene F (1931) Neue Ichthyosaurier aus Württemberg. N Jb Min Geol Paläont Abt B 65:305-320

Hui CA (1975) Thoracic collapse as affected by the retia thoracica in the dolphin. Respir Physiol 25:63-70

Humphries S, Ruxton GD (2002) Why did some ichthyosaurs have such large eyes? J Exp Biol 205:439-441

Hürlimann J, Feer P, Elber F, Niederberger K, Dirnhofer R, Wyler D (2000) Diatom detection in the diagnosis of death by drowning. Int J Leg Med 114:6-14

Innes S (1986) How fast should a dead whale cool? Can J Zool 64:2064-2065

Janßen F, Treude T, Witte U (2000) Scavenger assemblages under differing trophic conditions: a case study in the deep Arabian Sea. Deep-Sea Res Part II 47:2999-3026

Jauniaux T, Brosens L, Jacquinet E, Lambrigts D, Addink M, Smeenk C, Coignoul F (1998) Postmortem investigations on winter stranded sperm whales from the coasts of Belgium and the Netherlands. J Wildl Dis 34:99-109

Kahana T, Almog J, Levy J, Shmeltzer E, Spier Y, Hiss J (1999) Marine taphonomy: adipocere formation in a series of bodies recovered from a single shipwreck. J Forensic Sci 44:897-901

Kakizaki E, Takahama K, Seo Y, Kozawa S, Sakai M, Yukawa N (2008) Marine bacteria comprise a possible indicator of drowning in seawater. Forensic Sci Int 176:236-247

Kan T (1973) Studies on the determination of drowning from bones. Jpn J Leg Med 27:68-76

Kastelein RA, Dokter T, Hilgenkamp J (1995) A swimming support for dolphins undergoing veterinary care. Aquat Mamm 21:155-159

Kauffman EG (1981) Ecolocial Reappraisal of the German Posidonienschiefer and the Stagnant Basin Model. In: Gray J, Boucot AJ, Berry WBN (eds) Communities of the Past. Hutchinson Ross, Stroudsburg, pp 311-381 
Keil W, Bretschneider K, Patzelt D, Behning I, Lignitz E, Matz J (1980) Luftembolie oder Fäulnisgas? Zur Diagnostik der cardialen Luftembolie an der Leiche. Beitr Gerichtl Med 38:395-408

Keller T (1976) Magen- und Darminhalte von Ichthyosauriern des süddeutschen Posidonienschiefers. N Jb Geol Paläont Mh 5:266-283

Keller T (1992) "Weichteil-Erhaltung" bei großen Vertebraten (Ichthyosauriern) des Posidonienschiefers Holzmadens (Oberer Lias, Mesozoikum Süddeutschlands). Kaupia - Darmstädter Beitr Naturgesch 1:23-62

Kemp KM, Jamieson AJ, Bagley PM, McGrath H, Bailey DM, Collins MA, Priede IG (2006) Consumption of large bathyal food fall, a six month study in the NE Atlantic. Mar Ecol Progr Ser 310:65-76

Kemp RA (2001) Generation of the Solnhofen tetrapod accumulation. Archaeopteryx 19:11-28

Kiel S (2008) Fossil evidence for micro- and macrofaunal utilization of large nekton-falls: Examples from early Cenozoic deep-water sediments in Washington State, USA. Palaeogeogr Palaeoclimatol Palaeoecol 267:161-174

King NJ, Bagley PM, Priede IG (2006) Depth zonation and latitudinal distribution of deep-sea scavenging demersal fishes of the Mid-Atlantic Ridge, 42 to $53^{\circ} \mathrm{N}$. Mar Ecol Progr Seri 19:263-274

Kirkwood JK, Bennett PM, Jepson PD, Kuiken T, Simpson VR, Baker JR (1997) Entanglement in fishing gear and other causes of death in cetaceans stranded on the coasts of England and Wales. Vet Rec 141:94-98

Knieriem A, García Hartmann M (2001) Comparative histopathology of lungs from by-caught Atlantic white-sided dolphins (Leucopleurus acutus). Aquat Mamm 27:73-81

Knitter H, Ohmert W (1983) Das Toarcium der Schwärze bei Badenweiler (Oberrheingebiet S Freiburg). Jahresh geol L-A Baden Württemberg 25:233-281

Kooyman GL (1989) Diverse divers. Springer-Verlag, Berlin, Heidelberg

Koseki T (1968) Fundamental examinations of experimental materials and control animals on the diagnosis of death from drowning by the diatom method. Acta Med Biol 15:207-219

Krarup NT (1990) Hval. 19th November 1990, TV/ Midt-Vest, Holstebro, Denmark [video footage]

Kuhn-Schnyder E (1974) Die Triasfauna der Tessiner Kalkalpen. Neujahrsbl Natforsch Ges Zürich 176:1-119

Lam YM, Pearson OM, Marean CW, Chen X (2003) Bone density studies in zooarchaeology. J Archaeol Sci 30:1701-1708

Li ZH, Qin GM, Zhao YC, Li XL, Dong XT, Ma WX (2003) The development and changes of pressure of putrefactive gas in cadaveric enterocelia in spring and its forensic application. Fa Yi Xue Za Zhi [J Forensic Med] 19:72-75, in Chinese

Liebig PM, Flessa KW, Taylor T-SA (2007) Taphonomic Variation Dispite Catastrophic Mortality: Analysis of a Mass Stranding of False Killer Whales (Pseudorca crassidens), Gulf of California, Mexico. Palaios 22:384-391

Lingham-Soliar T, Wesley-Smith J (2008) First investigation of the collagen $D$-band ultrastructure in fossilized vertebrate integument. Proc Roy Soc Lond B 275:2207-2212

Lochner JV, Kauffman RG, Marsh BB (1980) Early-Postmortem Cooling Rate and Beef Tenderness. Meat Sci 4:227-241

Long C, Wings O, Xiaohong C, Sander M (2006) Gastroliths in the Triassic Ichthyosaur Panjiangsaurus from China. J Paleontol 80:583-588

Lucas J, Goldfeder LB, Gill JR (2002) Bodies found in the waterways of New York City. J Forensic Sci 47:137-141

Lunetta P, Penttila A, Sajantila A (2002) Circumstances and macropathologic findings in 1590 consecutive cases of bodies found in water. Am J Forensic Med Pathol 23:371-376

Lyamin O, Pryaslova J, Lance V, Siegel J (2006) Sleep Behaviour Lyamin et al. reply. Nature 441:E11

Maas MC (2002) Histology of Bones and Teeth. In: Perrin WF, Würsig B, Thewissen JGM (eds) Encyclopedia of Marine Mammals. Academic Press, San Diego, pp 116-122
Machel HG (1996) Roadkill as teaching aids in historical geology and paleontology. J Geosci Educ 44:270-276

Maisch MW (1999) Leptonectiden und Temnodontosauriden aus dem Alpha-Ölschiefer (Sinemurium) von Baden-Württemberg (SW-Deutschland). N Jb Geol Paläont Mh 1999(8):490-512

Maisch MW, Reisdorf AG (2006) Erratum to the article "Evidence for the longest stratigraphic range of a post-Triassic Ichthyosauria Leptonectes tenuirostris from the Pliensbachian (Lower Jurassic) of Switzerland". Geobios 39:743-746

Maisch MW, Reisdorf AG, Schlatter R, Wetzel A (2008) A large skull of Ichthyosaurus (Reptilia: Ichthyosauria) from the Lower Sinemurian (Lower Jurassic) of Frick (NW Switzerland). Swiss J Geosci 101:617-627

Mallach HJ, Schmidt WK (1980) Über ein quantitatives und qualitatives Verfahren zum Nachweis der Luft- oder Gasembolie. Beitr Gerichtl Med 38:409-419

Malakoff D (2001) Marine mammals: Scientists use strandings to bring species to life. Science 293:1754-1757

Mancuso AC, Marsicano CA (2008) Paleoenvironments and taphonomy of a Triassic lacustrine system (Los Rastros Formation, centralwestern Argentina). Palaios 23:535-547

Martill DM (1986) The stratigraphic distribution and preservation of fossil vertebrates in the Oxford Clay of England. Mercian Geol 10:161-188

Martill DM (1993) Soupy substrates: a medium for the exceptional preservation of ichthyosaurs of the Posidonia Shale (Lower Jurassic) of Germany. Kaupia - Darmstädter Beitr Natgesch 2:77-97

Martill DM, Cruickshank ARI, Taylor MA (1995) Speculations on the role of marine reptile deadfalls in Mesozoic deep-sea paleoecology; comment. Palaios 10:96-97

Martin J, Frey E, Riess J (1986) Soft tissue preservation in ichthyosaurs and a stratigraphic review of the Lower Hettangian of Barrow-uponSoar, Leicestershire. Trans Leic Lit Phil Soc 80:58-72

Mason CF, Macdonald SM (1986) Otters. Cambridge University Press, Cambridge

McGowan C (1978) Further evidence for the wide geographical distribution of ichthyosaur taxa (Reptilia: Ichthyosauria). J Paleont 52:1155-1162

McGowan C (1992) The ichthyosaurian tail: sharks do not provide an appropriate analogue. Palaeontology 35:555-570

McGowan C, Motani R (2003) Ichthyopterygia. In: Sues H-D (ed) Handbook of Paleoherpetology, Part 8, Verlag Dr. Friedrich Pfeil, München

McLellan WA, Papst DA, Westgate AJ, Koopman HN, Read AJ (1995) Post mortem cooling rates of harbor porpoise, Phocoena phocoena. International Whaling Commission Meeting 1995, SC/47/SM21 (unpublished), Dublin, Ireland

McLellan WA, Koopman HN, Rommel SA, Read AJ, Potter CW, Nicolas JR, Westgate AJ, Pabst DA (2002) Ontogenetic allometry and body composition of harbour porpoises (Phocoena phocoena, L.) from the western North Atlantic. J Zool Lond 257:457-471

Meyer CA (1991) Burial experiments with marine turtle carcasses and their paleoecological significance. Palaios 6:89-96

Meyer CA, Furrer H (1995) Taphonomie und paläoökologische Rekonstruktionen: Beispiele aus dem Mesozoikum des Jura. Eclog Geol Helv 88:711-720

Moreno P, Benke H, Lutter S (1992) Behaviour of Harbour (Phocoena phocoena) carcasses in the German Bight: surfacing rate, decomposition and drift routes. In: Bohlken $\mathrm{H}$, Benke $\mathrm{H}$ (eds) Untersuchungen über Bestand, Gesundheitszustand und Wanderungen der Kleinwalpopulationen (Cetacea) in deutschen Gewässern, unpublished Interim Report, WWF Fachbereich Wattenmeer \& Nordseeschutz und Forschungs- und Technologiezentrum Westküste, Außenstelle der Universität Kiel, Kiel, pp 1-4

Mosebach R (1952) Wässrige $\mathrm{H}_{2} \mathrm{~S}$-Lösungen und das Verschwinden kalkiger tierischer Hartteile aus werdenden Sedimenten. Senckenbergiana 33:13-22 
Motani R (2001) Body mass estimation from silhouettes: testing the assumption of elliptical body cross-sections. Paleobiol 27: $735-750$

Möttönen M, Nuutila M (1977) Post mortem injury caused by domestic animals, crustaceans, and fish. In: Tedeschi CG, Eckert WG, Tedeschi LG (eds) Forensic medicine: a study in trauma and environmental hazards, vol II, Physical Trauma. Saunders, Philadelphia, pp 1096-1098

Mueller B (1953) Gerichtliche Medizin. Springer, Berlin

Nowacek DP, Johnson MP, Tyack PL, Shorter KA, McLellan WA, Pabst DA (2001) Buoyant balaenids: the ups and downs of buoyancy in right whales. Proc Roy Soc Lond B 268:1811-1816

Øen EO (1983) Electrical Whaling: A Review. Nordisk Veterinaermed $35: 319-323$

Osborn HF (1905) Ichthyosaurs. The evolution of fitness in ichthyosaurs (Fossil wonders of the West). Cent Mag 69:414 422

Padosch SA, Dettmeyer RB, Kröner LU, Preuss J, Madea B (2005) An unusual occupational accident: fall into a sewage plant tank with lethal outcome. Forensic Sci Int 149:39-45

Pedal I, Moosmayer A, Mallach HJ, Oehmichen M (1987) Luftemoblie oder Fäulnis? Gasanalytische Befunde und ihre Interpretation. Z Rechtsmed 99:151-167

Perry SF (1983) Reptilian lungs: functional anatomy and evolution. Springer, Berlin

Petrik MS, Hobischak NR, Anderson GS (2004) Examination of factors surrounding freshwater decomposition in death investigations: a review of body recoveries and coroner cases in British Columbia. Can Soc Forensic Scie J 37:9-17

Piccard A (1961) In den Tiefen der Weltmeere. In: Wenzel H (ed) Das Meer. Kümmerly \& Frey, Geographischer Verlag, Bern, pp 105-126

Pierucci G, Gherson G (1968) Studio sperimentale sull'embolia gassosa con particolare riguardo alla differenziazione fra gas embolico e gas putrefattivo. Zaccia 43:347-373

Pompeckj JF (1901) Der Jura zwischen Regensburg und Regenstauf. Geogn Jahresh 14:139-220

Pratje O (1922) Lias und Rhät im Breisgau (Erster Teil). Mitt Großherzogl Bad Geol L-anstalt IX:277-352

Quenstedt FA (1858) Der Jura. Laupp \& Siebeck, Tübingen

Ramsey WL (1962) Bubble growth from dissolved oxygen near the sea surface. Limnol Oceanogr 7:1-7

Reiff W (1935) Saurierreste des Lias alpha der Langenbrückener Senke. Zbl Min Geol Paläont in Verbindung mit dem N Jb Min Geol Paläont Abt B, Jg 1935:227-253

Reisdorf AG (2007) No Joke Movement: Mehr über den Hauensteiner Ichthyosaurier und rezente marine Lungenatmer. Textnoten zur Physiologie, Pathologie und Taphonomie; weiterführende Literatur. Mitt Natforsch Ges Kanton Solothurn 40:23-49

Reisdorf AG, Maisch MW, Wetzel A (2011) First record of the leptonectid ichthyosaur Eurhinosaurus longirostris from the Early Jurassic of Switzerland and its stratigraphic framework. Swiss J Geosci 104:211-224

Reisdorf AG, Wuttke M (2012) Re-evaluating Moodie's OpisthotonicPosture Hypothesis in Fossil Vertebrates Part I: Reptiles - the taphonomy of the bipedal dinosaurs Compsognathus longipes and Juravenator starki from the Solnhofen Archipelago (Jurassic, Germany). In: Wuttke M, Reisdorf AG (eds) Taphonomic processes in terrestrial and marine environments. Palaeobio Palaeoenv 92(1). doi:10.1007/s12549-011-0068-y

de Ricqlès A, de Buffrénil V (2001) Bone histology, heterochronies and the return of Tetrapods to life in water: were are we. In: Mazin JM, de Buffrénil V (eds) Secondary adaptation of tetrapods to life in water. Friedrich Pfeil, München, pp 289-310

Ridgway SH, Scronce BL, Kanwisher J (1969) Respiration and deep diving in the bottlenose porpoise. Science 166:1651-1654

Ridgway SH (2002) Asymmetry and symmetry in brain waves from dolphin left and right hemispheres: some observations after anaesthesia during quiescent hanging behavior, and during visual obstruction. Brain Behav Evol 60:265-274

Robinson RHM, Ingram M, Case RAM, Benstead JG (1953) Whalemeat: Bacteriology and Hygiene. Department of Scientific and Industrial Research, Food Investigation: Spec Rep 59:1-56

Rodriguez WC (1997) Decomposition of buried and submerged bodies. In: Haglund WD, Sorg MH (eds) Forensic taphonomy - The postmortem fate of human remains. CRC Press, Boca Raton, pp 459467

Röhl H-J, Schmid-Röhl A, Oschmann W, Frimmel A, Schwark L (2001) Erratum to "The Posidonia Shale (Lower Toarcian) of SW-Germany: an oxygen-depleted ecosystem controlled by sea level and palaeoclimate". Palaeogeogr Palaeoclimatol Palaeoecol 169:273-299

Röhl H-J, Schmid-Röhl A (2005) Lower Toarcian (Upper Liassic) Black Shales of the Central European Epicontinental Basin: A Sequence Stratigraphic Case Study from the SW German Posidonia Shale. SEPM Soc Sed Geol Spec Publ 82:165-189

Rollo F, Luciani S, Marota I, Olivieri C, Ermini L (2007) Persistence and decay of the intestinal microbiota's DNA in glacier mummies from the Alps. J Archaeol Sci 34:1294-1305

Sakata M, Miki A, Kazama H, Morita M, Yasoshima S (1980) Studies on the composition of gases in the post-mortem body: animal experiments and two autopsy cases. J Forensic Sci 15:19-29

Sander PM (1989) The Pachypleurosaurids (Reptilia: Nothosauria) from the Middle Triassic of Monte San Giorgio (Switzerland) with the Description of a New Species. Philos Trans Roy Soc Lond B 325:561-666

Schäfer W (1972) Ecology and Palaeoecology of marine environments. University of Chicago Press, Chicago

Schieber W (1936) Der Untere und Mittlere Lias im württembergischbayerischen Grenzgebiet (Aalen-Wassertrüdingen). Dissertation, University of Tübingen

Schieber J, Southard J, Thaisen K (2007) Accretion of mudstone beds from migrating floccule ripples. Science 318:1760-1763

Schimmelmann A, Schuffert JD, Venkatesan MI, Leather J, Lange CB, Baturin GN, Simon A (1994) Biogeochemistry and origin of a phosphoritized coprolite from anoxic sediment of the Santa Barbara Basin. J Sed Res A64:771-777

Seilacher A (1982) Posidonia Shale (Toarcian, S. Germany) - Stagnate basin model revalidated. In: Gallitelli EM (ed) Palaeontology, essential of historical geology. STEM Mucchi, Modena, pp 25-55

Sekiguchi Y, Kohshima S (2003) Resting behaviors of captive bottlenose dolphins (Tursiops truncatus). Physiol Behav 79:643-653

Shafer NE, Zare RN (1991) Through a beer glass darkly. Phys Today 44:48-52

Sharp JG, Marsh BB (1953) Whalemeat: Production and Preservation. Department of Scientific and Industrial Research, Food Inv Spe Rep 58:1-47

Shevill WE, Ray C, Kenyon KW, Orr RT, Van Gelder RG (1967) Immobilizing Drugs Lethal to Swimming Mammals. Science 157:630-631

Siebert U, Wünschmann A, Weiss R, Frank H, Benke H, Frese K (2001) Post-mortem findings in harbour porpoises (Phocoena phocoena) from the German North and Baltic Seas. J Comp Pathol 124:102-114

Sims JK, Enomoto PI, Frankel RI, Wong LMF (1983) Marine bacteria complicating seawater near-drowning and marine wounds: a hypothesis. Ann Emerg Med 12:212-216

Slijper EJ (1962) Whales. Hutchinson, London

Smith CR, Baco AR (2003) Ecology of whale falls at the deep-sea floor. Oceanogr Mar Biol Ann Rev 41:311-354

Smith CR (2007a) Bigger is better: the role of whales as detritus in marine ecosystems. In: Estes JA, DeMaster DP, Doak DF, Williams TM, Brownel RL (eds) Whales, whaling and marine ecosystems. University of California Press, Berkeley, pp 286-300 
Smith CR (2007b) A Whale's End is the Beginning of Life at the Deep Seafloor. In: Nouvian C (ed) The Deep. University of Chicago Press, Chicago, pp 234-239

Smith K, Wuttke M (2012) From tree to shining sea: Taphonomy of the arboreal lizard Geiseltaliellus maarius from Messel, Germany. In: Wuttke M, Reisdorf AG (eds) Taphonomic processes in terrestrial and marine environments. Palaeobio Palaeoenv 92(1). doi:10.1007/s12549-011-0064-2

Sorg MH, Dearborn JH, Monahan EI, Ryan HF, Sweeney KG, David E (1997) Forensic taphonomy in marine contexts. In: Haglund WD, Sorg MH (eds) Forensic taphonomy - The postmortem fate of human remains. CRC Press, Boca Raton, pp 567-604

Staunton H (2005) Mammalian sleep. Naturwiss 92:203-220

Stede M, Lick R, Benke H (1996) Buckel- und Pottwale vor der ostfriesischen Küste: Probleme der Bergung und wissenschaftlichen Bearbeitung von Strandungen großer Walarten. Oldenb Jb 96:251-261

Stede M (1997) Probleme bei der Entsorgung von verendeten Meeressäugern. Dtsch Tierarztl Wochenschr 104:245-247

Stevens CE, Hume ID (1998) Contributions of Microbes in Vertebrate Gastrointestinal Tract to Production and Conservation of Nutrients. Physiol Rev 78:393-427

Sundborg A (1956) The river Klaraelven. A study of fluvial processes. Geograf Ann 38:125-131

Tarasoff FJ, Kooyman GL (1973) Observations on the anatomy of the river otter, sea otter, and harp seal. - II. The trachea and bronchial tree. Can J Zool 51:163-170

Taylor MA (1987) Reinterpretation of ichthyosaurs swimming and buoyancy. Palaeontology 30:531-535

Taylor MA (2000) Functional significance of bone ballastin in the evolution of buoyancy control strategies by aquatic tetrapods. Hist Biol 14:15-31

Taylor MA (2001) Locomotion in Mesozoic Marine Reptiles. In: Briggs DEG, Crowther PR (eds) Palaeobiology II. Blackwell, Oxford, pp 404-407

Thali MJ, Yen K, Schweitzer W, Vock P, Ozdoba C, Dirnhofer R (2003) Into the decomposed body-forensic digital autopsy using multislice-computed tomography. Forensic Sci Int 134:109-114

Tigress Productions (2008) The Whale That Blew Up In The Street. Nature Shock. Tigress Productions Ltd, Bristol [video footage]

Toklu AS, Alkan N, Gürel A, Cimsit M, Haktanır D, Körpinar S, Purisa S (2006) Comparison of pulmonary autopsy findings of the rats drowned at surface and $50 \mathrm{ft}$ depth. Forensic Sci Int 164:122-125

Tomita K (1975) On putrefactions and floatations of dead bodies under water. Hirosh J Med Sci 24:117-152

Tomita K (1976) On putrefactions and floatations of dead bodies under water (supplement). Hiroshima J Med Sci 25:155-174
Tønnessen JN, Johnsen AO (1982) The History of Modern Whaling. University of California Press, Berkeley

Tsokos M, Byard RW (2011) Putrefactive "rigor mortis". Forensic Sci Med Pathol [Epub ahead of print]. doi:10.1007/s12024011-9232-y

Vass AA, Barshick SA, Sega G, Caton J, Skeen JT, Love JC, Synstelien JA (2002) Decomposition chemistry of human remains: a new methodology for determining the postmortem interval. J Forensic Sci 47:542-553

Wade M (1984) Platypterygius australis, an Australian Cretaceous ichthyosaur. Lethaia 17:99-113

Wartzok D (2002) Breathing. In: Perrin WF, Würsig B, Thewissen JGM (eds) Encyclopedia of Marine Mammals. Academic Press, San Diego, pp 164-169

Wasmund E (1935) Die Bildung von anabituminösem Leichenwachs unter Wasser. Schr Brennstoffgeol 10:1-70

Weiss RF, Price BA (1989) Dead Sea gas solubilities. Earth Planet Sci Lett 92:7-10

Westphal F (1962) Die Krokodilier des deutschen und englischen Oberen Lias. Palaeontographica A 118:23-118

Wetzel A (1990) Interrelationships between porosity and other geotechnical properties of slowly deposited, fine-grained marine surface sediments. Mar Geol 92:105-113

Wetzel A, Reisdorf AG (2007) Ichnofabrics elucidate the accumulation history of a condensed interval containing a vertically emplaced ichthyosaur skull. SEPM Soc Sed Geol Spec Publ $88: 241-251$

Widdel F (1988) Microbiology and ecology of sulfate- and sulfurreducing bacteria. In: Zehnder ABJ (ed) Biology of Anaerobic Microorganisms. Wiley, New York, pp 469-585

Wild R (1978) Ein Sauropoden-Rest (Reptilia, Saurischia) aus dem Posidonienschiefer (Lias, Toarcium) von Holzmaden. Stuttg Beitr Natkd Ser B 41:1-15

Williams TM, Davis RW, Fuiman LA, Francis J, Le Boeuf BJ, Horning M, Calambokidis J, Croll DA (2000) Sink or swim: Strategies for cost-efficient diving by marine mammals. Science 288:133-136

Worthy GAJ, Edwards EF (1990) Morphometric and Biochemical Factors Affecting Heat Loss in a Small Temperate Cetacean (Phocoena phocoena) and a Small Tropical Cetacean (Stenella attenuata). Physiol Zool 63:1012-1024

Yoshimura S, Yoshida M, Okii Y, Tokiyasu T, Watabiki T, Akane A (1995) Detection of green algae (Chlorophyceae) for the diagnosis of drowning. Int J Leg Med 108:39-42

Zangerl R, Richardson ES (1963) The paleoecological history of two Pennsylvanian black shales. Fieldiana-Geol Mem 4:1-352 